\title{
Persicarin isolated from Oenanthe javanica protects against diabetes-induced oxidative stress and inflammation in the liver of streptozotocin-induced type 1 diabetic mice
}

\author{
JOO YOUNG LEE ${ }^{1}$, MIN YEONG KIM ${ }^{1}$, SUNG HO SHIN ${ }^{1}$, MI-RAE SHIN ${ }^{1}$, \\ O JUN KWON ${ }^{2}$, TAE HOON KIM ${ }^{3}$, CHAN HUM PARK ${ }^{4}$, JEONG SOOK NOH ${ }^{5}$, \\ MAN HEE RHEE ${ }^{6}$ and SEONG-SOO ROH ${ }^{1}$
}

\author{
${ }^{1}$ Department of Herbology, College of Korean Medicine, Daegu Haany University, Daegu 706-060; \\ ${ }^{2}$ Kyeoungbuk Institute for Regional Program Evaluation, Gyeongsan, Gyeongsangbuk 38542; \\ ${ }^{3}$ Department of Food Science \& Biotechnology, Daegu University, Gyeongsan, Gyeongsangbuk 38453; \\ ${ }^{4}$ Department of Medicinal Crop Research, National Institute of Horticultural and Herbal Science, \\ Rural Development Administration, Eumseong, Gyeongsangbuk 27710; ${ }^{5}$ Department of Food Science \& Nutrition, \\ Tongmyong University, Busan, Gyeongsangnam 48520; ${ }^{6}$ Department of Veterinary Medicine, \\ College of Veterinary Medicine, Kyungpook National University, Daegu 41566, Republic of Korea
}

Received July 13, 2015; Accepted September 9, 2016

DOI: $10.3892 / \mathrm{etm} .2017 .4113$

\begin{abstract}
Persicarin is one of the major components of the Oenanthe javanica (water dropwort). The present study was aimed to evaluate the role of persicarin in the hepatic tissue of streptozotocin-induced type 1 diabetic mice. Diabetes was induced by single intra-peritoneal injection of streptozotocin (120 mg/kg body weight) and then oral administration of persicarin at a dose 2.5 and $5 \mathrm{mg} / \mathrm{kg}$ body weight for 10 days Serum and hepatic glucose levels were increased in diabetic control mice, while persicarin treatment groups were markedly reduced. Also, the increased levels of ALT and AST in serum were improved by persicarin. In our results revealed that persicarin suppressed increased oxidative stress parameter (reactive oxygen species, peroxinitrite, and thiobarbituric acid-reactive substance), nicotinamide adenine dinucleotide phosphate oxidase subunit (Nox-4 and P47 ${ }^{\text {phox }}$ ) and inflammatory related makers $(\mathrm{NF}-\kappa \mathrm{B}, \mathrm{AP}-1, \mathrm{TGF}-\beta, \mathrm{COX}-2$, and iNOS). These results suggest that persicarin protects against liver damage by attenuating oxidative stress and inflammatory response under hyperglycemic conditions. Thus, persicarin could perform as a potential therapeutic agent for the treatment of diabetic mellitus.
\end{abstract}

Correspondence to: Professor Seong-Soo Roh, Department of Herbology, College of Korean Medicine, Daegu Haany University, 64 Gil, 25 Suseong-gu, Daegu 706-060, Republic of Korea

E-mail:ddede@dhu.ac.kr

Key words: persicarin, Oenanthe javanica, streptozotocin, type 1 diabetes, oxidative stress, inflammation

\section{Introduction}

Diabetes has become one of the most important diseases worldwide, with the proportion of the adult population with diabetes expected to increase to $69 \%$ by 2030 (1). Diabetes mellitus is a metabolic disease characterized by prolonged hyperglycemia, which can lead to the development of microvascular and macrovascular disease (2). Hyperglycemia at the macrovascular level causes coronary artery and cerebrovascular diseases, and at the microvascular level injury mainly affects the eye, kidney and liver. Diabetic hepatic damage is the most common cause of end-stage liver disease, namely cirrhosis, and contributes to disability and the high mortality rate in patients with diabetes. The pathogenesis of diabetic hepatic damage is multifactorial, with long-term hyperglycemia playing a crucial role $(3,4)$. During diabetes mellitus, the continuous hyperglycemic conditions are associated with oxidative stress and the mitochondrial production of free radicals, which lead to hepatic dysfunction (5). One of the main factors in the initiation of the pathological response to oxidative stress is the generation of reactive oxygen species (ROS). According to a previous study, increased nicotinamide adenine dinucleotide phosphate (NADPH) oxidase-4 (Nox-4)/p47 $7^{\text {phox }}$ is associated with elevated ROS generation, implying the potential importance of Nox-4-based NADPH oxidase in the oxidative damage associated with diabetic hepatism (6). Moreover, increased ROS production is associated with inflammation and indirectly damages cells by activating a variety of stress-sensitive intracellular signaling pathways. Also, ROS-mediated activation of nuclear factor $(\mathrm{NF})-\kappa \mathrm{B}$ and the c-Jun subunit of activator protein-1 (AP-1), two redox-sensitive transcription factors, are evolutionarily conserved and associated with a wide variety of pro-inflammatory mediators, including cytokines, chemokines, and 
inducible effector enzymes such as inducible nitric oxide synthase (iNOS) and cyclooxygenase-2 (COX-2) (7).

Oenanthe javanica (water dropwort), which is cultivated in Australia and East Asian countries, such as Korea, China and Japan is a perennial herb. O. javanica, which contains high levels of vitamins and minerals, is consumed as a vegetable, and has also been used as a medicinal agent. It has a long history of use for the treatment of inflammatory conditions, including hepatitis $(8,9)$. Hyperoside, persicarin and isorhamnetin are the three major substances with pharmacological activities that have been identified in $O$. javanica. These substances have been shown to possess hepatoprotective, antithrombotic, antiarrhythmic, antidiabetic, antihepatitis B virus, neuroprotective and anticancer activities (9-16).

Persicarin has been reported to exhibit neuroprotective and antioxidant activities against glutamate-induced neurotoxicity in primary cultured rat cortical cells (14). In addition, persicarin has exhibited an anti-inflammatory effect against high mobility group box 1-induced inflammatory responses in human endothelial cells and in a cecal ligation and puncture model of septicemia in mice (17). However, to the best of our knowledge, no studies have yet been performed on the antidiabetic activity of persicarin.

Therefore, in the present study, the effects of persicarin on the oxidative stress-related factors involved in the development of diabetic hepatic damage were investigated using streptozotocin (STZ)-induced type 1 diabetic mice.

\section{Materials and methods}

Materials. Ethylenediaminetetraacetic acid (EDTA) was purchased from Generay Biotech Co. Ltd. (Shanghai, China). 2',7'-Dichlorofluorescein diacetate (DCFH-DA) was obtained from Molecular Probes (Thermo Fisher Scientific, Inc., Waltham, MA, USA). The protease inhibitor mixture was purchased from Wako Pure Chemical Industries, Ltd. (Osaka, Japan). Dihydrorhodamine 123 (DHR123) and diethylene triamine penta-acetic acid (DTPA) were purchased from Sigma-Aldrich (Merck Millipore, Darmstadt, Germany). Isoflurane (1\%) was purchased from Piramal Critical Care, Inc., (Bethlehem, PA, USA). The Bio-Rad protein assay kit and pure nitrocellulose membrane were supplied by Bio-Rad Laboratories (Seoul, Korea). Phenylmethylsulfonyl fluoride (PMSF) and sodium dodecyl sulfate (SDS) were acquired from (Amresco, LLC, Solon, OH, USA). PBS-Tween (P2006) was obtained from Biosesang, Inc., (Gyeonggi-do, Korea). Rabbit polyclonal antibodies against Nox-4 (cat. no. sc-30141), p47phox (cat. no. sc-14015) and NF-кBp65 (cat. no. sc-372), and mouse monoclonal antibodies against COX-2 (cat. no. sc-19999), iNOS (cat. no. sc-372), histone (cat. no. sc-8030) and $\beta$-actin (cat. no. sc-4778), and goat polyclonal antibodies against transforming growth factor (TGF)- $\beta$ (cat. no. sc-146) and tumor necrosis factor (TNF)- $\alpha$ (cat. no. sc-1351) were purchased from Santa Cruz Biotechnology, Inc. (Dallas, TX, USA). Rabbit polyclonal anti-AP-1 (cat. no. 2315S) was obtained from Cell Signaling Technology, Inc. (Danvers, MA, USA). Goat anti-rabbit (cat. no. sc-2774) and goat anti-mouse (cat. no. sc-2005) immunoglobulin G (IgG) horseradish peroxidase (HRP)-conjugated secondary antibodies were acquired from Santa Cruz Biotechnology, Inc. ECL Western
Blotting Detection Reagents were supplied by GE Healthcare (Piscataway, NJ, USA).

Preparation of persicarin extracts. The aerial parts of $O$. javanica were collected from agricultural farms in Pyeongyang-ri, Cheongdo-gun, Gyoungsanbuk-do, South Korea in April 2011, and identified by Professor Tae Hoon Kim (Daegu University, Daegu, South Korea). Freshly milled O. javanica plant material $(1.4 \mathrm{~kg})$ was extracted with $70 \%$ ethanol $(\mathrm{EtOH}$; 10 liters, thrice) at room temperature. The solvent was then evaporated under vacuum, and the combined crude EtOH extract (81.5 g) was suspended in 20\% methanol (MeOH; 3 liters), and partitioned sequentially against $n$-hexane (3 liters, thrice), ethyl acetate (EtOAc; 3 liters, thrice), and $n$-butanol (BuOH; 3 liters, thrice) to yield dried $n$-hexane-(5.5 g), EtOAc- $(1.8 \mathrm{~g}), n$-BuOH (10.6 g) and $\mathrm{H}_{2} \mathrm{O}$-soluble $(53.6 \mathrm{~g})$ residues. A portion $(1.7 \mathrm{~g})$ of the EtOAc extract was chromatographed using a column containing Toyopearl HW-40 [coarse grade; $3.0 \mathrm{~cm}$ internal diameter (i.d.)x48 cm] using water containing increasing amounts of $\mathrm{MeOH}$ in a stepwise manner. The $100 \% \mathrm{H}_{2} \mathrm{O}$ eluate obtained was subjected to column chromatography using YMC GEL ODS AQ 120-50S (1.6 cm i.d.x37 cm) using aqueous $\mathrm{MeOH}$, to yield pure compound 1 (75.9 mg; retention time, $10.1 \mathrm{~min})$. HPLC analysis was carried out using a YMC-Pack ODS A-302 column (4.6 mm i.d.x150 mm; YMC Co., Kyoto, Japan) with a linear gradient of $10 \%(\mathrm{v} / \mathrm{v})$ acetonitrile $(\mathrm{MeCN})$ in $0.1 \%$ formic acid $/ \mathrm{H}_{2} \mathrm{O}$ (detection, UV $280 \mathrm{~nm}$; flow rate, $1.0 \mathrm{ml} / \mathrm{min} ; 40^{\circ} \mathrm{C}$ ), which was increased to $90 \% \mathrm{MeCN}$ over $30 \mathrm{~min}$ and then to $100 \% \mathrm{MeCN}$ over $5 \mathrm{~min}$. Compound 1 was identified and characterized as persicarin by ${ }^{1} \mathrm{H}$ and ${ }^{13} \mathrm{C}$ NMR and by comparing peaks with literature values (18). The ${ }^{1} \mathrm{H}$ NMR results were as follows: $\left(600 \mathrm{MHz}, \mathrm{DMSO}-\mathrm{d}_{6}\right) \delta 8.06$ $\left(1 \mathrm{H}, \mathrm{d}, \mathrm{J}=2.2 \mathrm{~Hz}, \mathrm{H}-2^{\prime}\right), 7.61$ (1H, d, J=8.8, 2.2 Hz, H-6'), 6.92 $(1 \mathrm{H}, \mathrm{d}, \mathrm{J}=8.8 \mathrm{~Hz}, \mathrm{H}-5$ '), 6.43 (1H, d, J=2.2 Hz, H-8), $6.22(1 \mathrm{H}$, d, J=2.2 Hz, H-6), 3.83 (3H, s, MeO-3'). The ${ }^{13} \mathrm{C}$ NMR results were as follows: (150 MHz, DMSO- $\left.\mathrm{d}_{6}\right) \delta 177.1$ (C-4), 166.5 (C-7), 161.1 (C-5), 156.2 (C-2), 155.5 (C-9), 149.6 (C-3'), 147.1 (C-4'), 131.8 (C-5'), 121.2 (C-6'), 121.1 (C-1'), 115.2 (C-2'), 103.1 (C-10), 99.7 (C-6), 93.6 (C-8), $55.6(\mathrm{MeO})$.

Experimental animals and treatment. Animal experiments were performed according to the Guidelines for Animal Experimentation and approved by Daegu Haany University (approval no. DHU2015-011). A total of 24, 5-week-old male ICR mice (23-28 g) were purchased from Orient Bio Inc. (Gyeonggi, Korea). Mice were maintained under a 12-h light/dark cycle, and housed at a controlled temperature $\left(22 \pm 2^{\circ} \mathrm{C}\right)$ and humidity $(55 \pm 5 \%)$ with free access to food and water. After several days of adaptation, the mice were randomly separated into normal control $(n=6)$ and diabetic groups. Mice in the diabetic group were injected intraperitoneally with STZ (Sigma-Aldrich; $120 \mathrm{mg} / \mathrm{kg}$ body weight) in $10 \mathrm{mM}$ citrate buffer ( $\mathrm{pH} \mathrm{4.5)}$. After 7 days of STZ injection, the glucose levels of blood taken from the tail vein were measured, and then the STZ-induced diabetic mice were divided into three groups (each $n=6$ ). Treatment with persicarin was initiated after confirming the induction of hyperglycemia in the diabetic mice by weight $(33.8 \pm 0.5 \mathrm{~g})$ and serum glucose level $(288.3 \pm 6.5 \mathrm{mg} / \mathrm{dl})$. Mice in the diabetic control group (Veh group) were given water orally, while those in the other two diabetic groups were orally 
treated with persicarin extracts daily for 10 days at a low or high dose (2.5 and $5 \mathrm{mg} / \mathrm{kg}$ body weight, respectively). The diabetic groups were compared with the normal (non-diabetic) control group. Body weight, food intake and water intake were determined every day during the experimental period. After administration for 10 days, mice were anesthetized with $1 \%$ isoflurane and blood samples were collected from the abdominal aorta of anesthetized mice. Serum was separated immediately by centrifugation. Subsequently, each mouse was perfused with ice-cold physiological saline, and then the liver was harvested, snap-frozen in liquid nitrogen and stored at $-80^{\circ} \mathrm{C}$ until analyses were performed.

Analysis of serum and hepatic functional parameters. The serum glucose level was measured using a commercial kit (Glucose Test, cat. no. AM201; Asan Pharm. Co., Ltd., Hwaseong, South Korea). Hepatic functional parameters [alanine aminotransferase (ALT) and aspartate aminotransferase (AST)] were measured using a Transaminase CII-Test kit (cat. no. 431-30901; Wako Pure Chemical Industries, Ltd.).

Analysis of hepatic glucose content. The hepatic glucose level was determined using the method of Momose et al (19), with minor modifications. Hepatic tissue was homogenized with ice-cold $0.9 \% \mathrm{NaCl}$ buffer, and then the homogenate was deproteinized with $0.15 \mathrm{M} \mathrm{Ba}(\mathrm{OH})_{2}$ and $5 \% \mathrm{ZnSO}_{4}$. The supernatant was obtained by centrifugation at $1,670 \mathrm{x} \mathrm{g}$ for $15 \mathrm{~min}$, and then the glucose level was determined using the aforementioned glucose test kit.

Measurement of hepatic ROS generation and thiobarbituric acid reactive substance (TBARS) levels. ROS generation was measured using the method of Ali et al (20). Hepatic tissue was homogenized on ice with $1 \mathrm{mM}$ EDTA-50 mM sodium phosphate buffer ( $\mathrm{pH} 7.4$ ), and then $25 \mathrm{mM}$ DCFH-DA was added to the homogenates. After incubation for $30 \mathrm{~min}$, the changes in fluorescence values were determined at an excitation wavelength of $486 \mathrm{~nm}$ and emission wavelength of $530 \mathrm{~nm}$. The TBA-reactive substance content was determined using the method of Mihara and Uchiyama (21).

Measurement of peroxynitrite $\left(\mathrm{ONOO}^{-}\right)$generation in the liver. $\mathrm{ONOO}^{-}$was measured by the method of Kooy et al (22). Each sample was mixed with rhodamine buffer $(\mathrm{pH} 7.4)$, $5 \mathrm{mM}$ DTPA and $5 \mathrm{mM} \mathrm{DHR} 123$. After incubation for $5 \mathrm{~min}$ at $37^{\circ} \mathrm{C}$, the fluorescence intensity of the oxidized DHR 123 was measured with a microplate fluorescence reader at excitation and emission wavelengths of 485 and $530 \mathrm{~nm}$, respectively.

Preparation of nuclear and post-nuclear fractions. Nuclear protein extraction was performed using the method reported by Komatsu (23). Briefly, liver tissue was homogenized with ice-cold lysis buffer containing $5 \mathrm{mM}$ Tris- $\mathrm{HCl}(\mathrm{pH} 7.5)$, $2 \mathrm{mM} \mathrm{MgCl}_{2}, 15 \mathrm{mM} \mathrm{CaCl}_{2}$ and $1.5 \mathrm{M}$ sucrose, followed by the addition of a $0.1 \mathrm{M}$ dithiothreitol (DTT) and a protease inhibitor mixture. After centrifugation $(10,500 \mathrm{x} g$ for $20 \mathrm{~min}$ at $4^{\circ} \mathrm{C}$ ), the pellet was suspended with an extraction buffer containing $20 \mathrm{mM}$ 2-[4-(2-hydroxyethyl)-1-piperazyl] ethanesulfonic acid (pH 7.9), $1.5 \mathrm{mM} \mathrm{MgCl}_{2}, 0.42 \mathrm{M} \mathrm{NaCl}, 0.2 \mathrm{mM}$ EDTA and $25 \%(\mathrm{v} / \mathrm{v})$ glycerol, followed by the addition of a
0.1 M DTT and protease inhibitor mixture. The mixture was placed on ice for $30 \mathrm{~min}$. The nuclear fraction was prepared by centrifugation at 20,500 $\mathrm{xg}$ for $5 \mathrm{~min}$ at $4^{\circ} \mathrm{C}$.

The post-nuclear fraction was extracted from the kidneys of each mouse. Briefly, liver tissue was homogenized with ice-cold lysis buffer ( $\mathrm{pH}$ 7.4) containing $137 \mathrm{mM} \mathrm{NaCl}$, $20 \mathrm{mM}$ Tris- $\mathrm{HCl}, 1 \%$ Tween 20, 10\% glycerol, 1 mM PMSF, and a protease inhibitor mixture. The homogenate was then centrifuged at $2,000 \mathrm{x} \mathrm{g}$ for $10 \mathrm{~min}$ at $4^{\circ} \mathrm{C}$, and the protein concentration in each fraction was determined using a Bio-Rad protein assay kit.

Western blot analyses. To determine the expression of $\mathrm{NF}-\kappa \mathrm{Bp} 65$, AP-1 and histone, $10 \mu \mathrm{g}$ protein from each nuclear fraction was separated by $8 \%$ SDS-PAGE. For Nox-4/p47phox, COX-2, iNOS, TGF- $\beta$ and $\beta$-actin , $10 \mu \mathrm{g}$ protein of each post-nuclear fraction was separated by $8-15 \%$ SDS-PAGE. The separated proteins were transferred to a nitrocellulose membrane, blocked with a $5 \%(\mathrm{w} / \mathrm{v})$ skimmed milk solution for $1 \mathrm{~h}$, and incubated separately with the primary antibodies (NF-кBp65, AP-1, histone, Nox-4/p47 phox COX-2, iNOS, TGF- $\beta$ and $\beta$-actin) overnight at $4^{\circ} \mathrm{C}$ at a dilution of $1: 1,000$. Following washing with PBS-Tween, the blots were incubated with the anti-rabbit or anti-mouse IgG HRP-conjugated secondary antibody for $1 \mathrm{~h}$ at room temperature at a dilution of 1:3,000. Each antigen-antibody complex was visualized using ECL Western Blotting Detection Reagents and detected using SENSI-Q2000 (Lugen Sci. Co., Ltd., Gyeonggi, South Korea). The band densities were determined using ATTO Densitograph software (CS Analyzer 2.0; ATTO Corporation, Tokyo, Japan), and quantified as a ratio to $\beta$-actin. The protein levels of the groups are expressed relative to those of the normal mice (represented as 1 ).

Histological examination. The excised liver samples were immediately fixed in $10 \%$ neutral-buffered formalin and, after embedding in paraffin, they were cut into 5- $\mu \mathrm{m}$ sections. After staining with hematoxylin and eosin $(\mathrm{H} \& \mathrm{E})$, the sections were examined with a light microscope.

Statistical analysis. Data are expressed as the mean \pm standard error of the mean. Statistical comparisons were performed using one-way analysis of variance followed by a Dunnett's test using SPSS 11.5.1 for Windows, 2002 (SPSS Inc., Chicago, IL, USA). $\mathrm{P}<0.05$ was considered to indicate a statistically significant difference.

\section{Results}

Body weight gain, liver weight, food intake and water intake. The body weight gains, liver weight, food intake and water intake during the experimental period are shown in Table I. The diabetic control mice showed a significant reduction in body weight in comparison with non-diabetic mice. However, the body weights of mice treated with persicarin were notably higher than those diabetic control mice. In addition, the administration of persicarin did not affect food and water intake, but the liver weight was significantly increased by 1.19- and 1.2-fold in the low and high dose groups, respectively. 
Table I. Body weight, liver weight, food intake, and water intake.

\begin{tabular}{|c|c|c|c|c|c|c|}
\hline \multirow[b]{2}{*}{ Group } & \multicolumn{3}{|c|}{ Body weight } & \multirow{2}{*}{$\begin{array}{c}\text { Liver weight } \\
\text { (g/100 g body weight) }\end{array}$} & \multirow{2}{*}{$\begin{array}{l}\text { Food intake } \\
\text { (g/day) }\end{array}$} & \multirow{2}{*}{$\begin{array}{l}\text { Water intake } \\
\text { (g/day) }\end{array}$} \\
\hline & Initial (g) & Final (g) & Gain (g/10 days) & & & \\
\hline Non-diabetic mice & $38.9 \pm 0.6^{\mathrm{a}}$ & $42.0 \pm 0.6^{\mathrm{a}}$ & $3.6 \pm 0.2^{\mathrm{a}}$ & $7.9 \pm 0.3^{\mathrm{a}}$ & $5.1 \pm 2.6$ & $6.1 \pm 3.0$ \\
\hline \multicolumn{7}{|l|}{ Diabetic mice } \\
\hline Veh & $33.9 \pm 0.8$ & $33.2 \pm 0.8$ & $-1.3 \pm 0.2$ & $6.1 \pm 0.1$ & $8.4 \pm 0.5$ & $28.7 \pm 4.9$ \\
\hline Low & $33.8 \pm 1.1$ & $33.9 \pm 1.5$ & $-0.4 \pm 0.3^{b}$ & $7.3 \pm 0.3^{\mathrm{b}}$ & $7.8 \pm 0.2$ & $35.2 \pm 3.4$ \\
\hline High & $33.8 \pm 1.1$ & $33.3 \pm 1.2$ & $0 \pm 0.2^{\mathrm{a}}$ & $7.3 \pm 0.1^{\mathrm{a}}$ & $8.4 \pm 0.4$ & $38.6 \pm 4.0$ \\
\hline
\end{tabular}

Data are presented as the mean \pm standard error of the mean $(n=6) .{ }^{a} \mathrm{P}<0.001,{ }^{b} \mathrm{P}<0.01$ vs. vehicle-treated diabetic mice. Veh, vehicle-treated diabetic mice; low, persicarin $2.5 \mathrm{mg} / \mathrm{kg}$ body weight-treated diabetic mice; high, persicarin $5 \mathrm{mg} / \mathrm{kg}$ body weight-treated diabetic mice.

Table II. Biochemical analyses.

Diabetic mice

\begin{tabular}{|c|c|c|c|c|}
\hline \multirow[b]{2}{*}{ Variable } & \multirow[b]{2}{*}{ Non-diabetic mice } & \\
\hline & & Veh & Low & High \\
\hline Serum glucose (mg/dl) & $122.15 \pm 5.54^{\mathrm{a}}$ & $597.12 \pm 7.39$ & $533.96 \pm 9.94^{\mathrm{a}}$ & $513.11 \pm 19.86^{b}$ \\
\hline Hepatic glucose (mg/mg protein) & $31.53 \pm 1.50^{\mathrm{c}}$ & $36.73 \pm 0.46$ & $34.47 \pm 1.81$ & $33.56 \pm 0.35^{\mathrm{a}}$ \\
\hline Serum ALT (IU/l) & $15.43 \pm 0.73^{\mathrm{a}}$ & $31.27 \pm 0.30$ & $27.32 \pm 1.69$ & $25.64 \pm 0.51^{\mathrm{a}}$ \\
\hline Serum AST (IU/l) & $51.98 \pm 3.49^{\mathrm{a}}$ & $120.08 \pm 4.27$ & $93.32 \pm 1.01^{\mathrm{a}}$ & $86.03 \pm 3.09^{\mathrm{a}}$ \\
\hline
\end{tabular}

Data are presented as the mean \pm standard error of the mean. ${ }^{\mathrm{a}} \mathrm{P}<0.001,{ }^{\mathrm{b}} \mathrm{P}<0.01,{ }^{\mathrm{c}} \mathrm{P}<0.05$ vs. vehicle-treated diabetic mice. Veh, vehicle-treated diabetic mice; low, persicarin $2.5 \mathrm{mg} / \mathrm{kg}$ body weight-treated diabetic mice; high, persicarin $5 \mathrm{mg} / \mathrm{kg}$ body weight-treated diabetic mice; ALT, alanine aminotransferase; AST, aspartate aminotransferase.

A

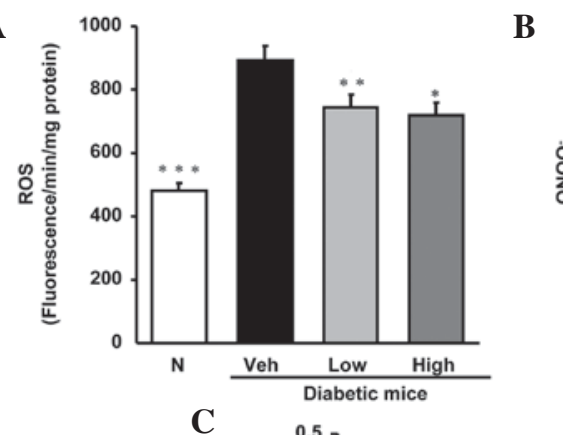

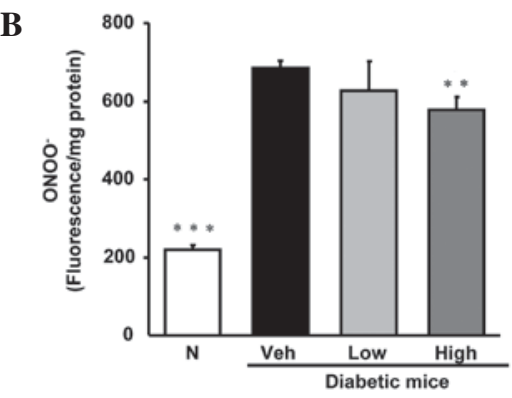

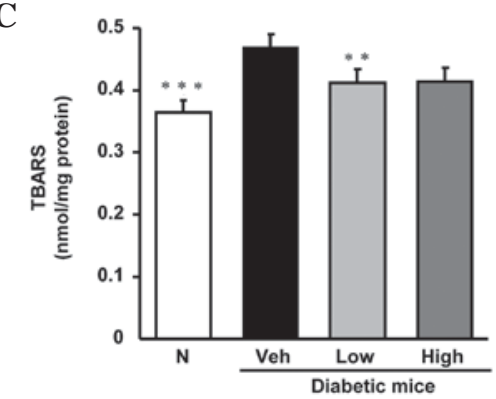

Figure 1. Levels of (A) ROS, (B) ONOO- and (C) TBARS in hepatic tissue. N, non-diabetic mice; veh, vehicle-treated diabetic mice; low, persicarin 2.5 mg/kg body weight-treated diabetic mice; high, persicarin $5 \mathrm{mg} / \mathrm{kg}$ body weight-treated diabetic mice. Data are the means \pm standard error of the mean $(\mathrm{n}=6)$. ${ }^{*} \mathrm{P}<0.05$, ${ }^{* *} \mathrm{P}<0.01,{ }^{* * *} \mathrm{P}<0.001$ vs. vehicle-treated diabetic mice. ROS, reactive oxygen species; ONOO-, peroxynitrite; TBARS, thiobarbituric acid-reactive substance.

Serum and hepatic functional parameters. Table II shows that the serum glucose level was significantly increased in diabetic control mice; the increase was $\sim 4$-fold in comparison with that in non-diabetic mice. Persicarin treatment led to 
A
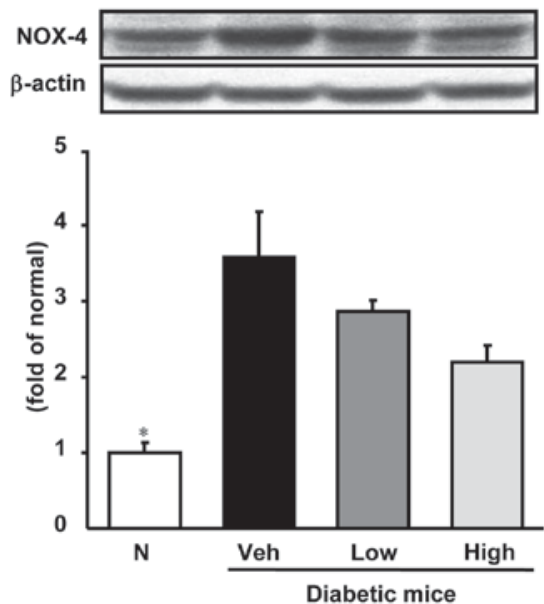

B
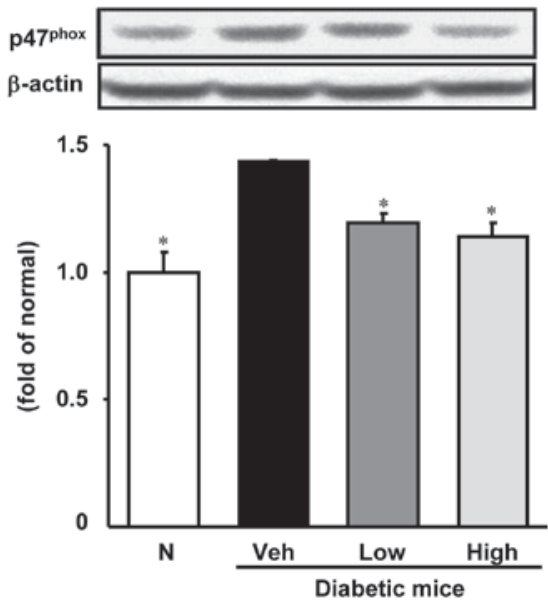

Figure 2. Expression of (A) Nox-4 and (B) p47phox protein in hepatic tissue. N, non-diabetic mice; veh, vehicle-treated diabetic mice; low, persicarin 2.5 mg/kg body weight-treated diabetic mice; high, persicarin $5 \mathrm{mg} / \mathrm{kg}$ body weight-treated diabetic mice. Data are the means \pm standard error of the mean ( $=6$ ). ${ }^{*} \mathrm{P}<0.001$ vs. vehicle-treated diabetic mice.

A
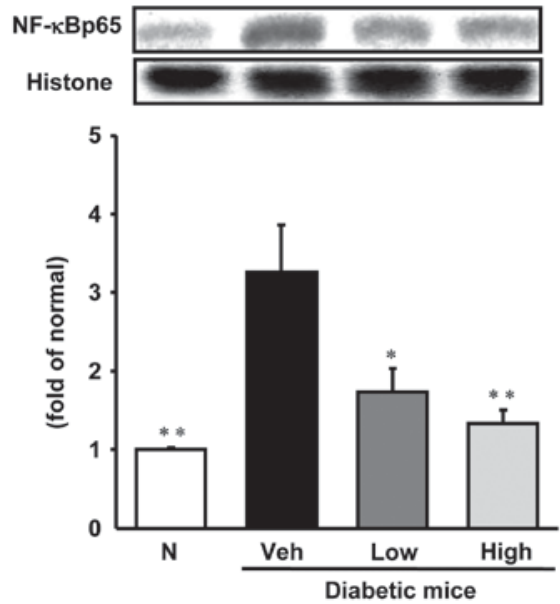

B
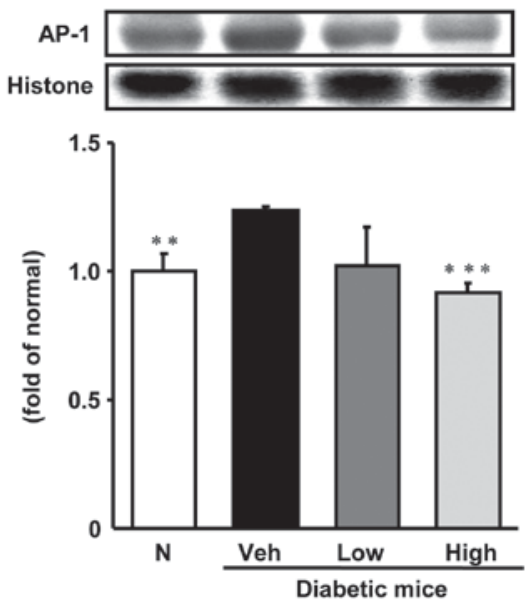

Figure 3. Expression of (A) NF-кBp65 and (B) AP-1 protein expressions in hepatic tissue. N, non-diabetic mice; veh, vehicle-treated diabetic mice; low, persicarin $2.5 \mathrm{mg} / \mathrm{kg}$ body weight-treated diabetic mice; high, persicarin $5 \mathrm{mg} / \mathrm{kg}$ body weight-treated diabetic mice; NF- $\mathrm{Kp} 65$, nuclear factor- $\kappa$ B; AP-1, activator protein-1. Data are the means \pm standard error of the mean $(\mathrm{n}=6) .{ }^{*} \mathrm{P}<0.05,{ }^{* *} \mathrm{P}<0.01,{ }^{* * *} \mathrm{P}<0.001$ vs. vehicle-treated diabetic mice.

a notable reduction of glucose level in a dose-dependent manner. Hepatic functional parameters, namely ALT and AST levels in the serum, of vehicle- and persicarin-treated diabetic mice were investigated. The activities of ALT and AST in the diabetic mice were significantly higher than those of normal mice, while their activities in the persicarin treatment groups were markedly reduced in a dose-dependent manner.

Hepatic glucose. As Table II demonstrates, persicarin exhibited an effect on hepatic glucose. Persicarin administration markedly reduced hepatic glucose levels at a dose of $5 \mathrm{mg} / \mathrm{kg}$.

Biomarkers associated with oxidative stress in hepatic tissue. As shown in Fig. 1, the biomarkers of oxidative stress, namely ROS, ONOO- and TBARS in diabetic control mice were notably elevated compared with those in normal mice. However, the elevated levels were diminished by oral treatment with persicarin.
Expression of NADPH oxidase subunits Nox-4 and $p 47^{\text {phox }}$ in hepatic tissue. The results of western blot analysis of hepatic Nox-4 and p47 phox protein in the hepatic tissues of the four groups are shown in Fig. 2. Persicarin administration showed a tendency to decrease the Nox-4 level (although the reduction was not statistically significant), whereas the $\mathrm{p} 47^{\mathrm{phox}}$ protein expression level was significantly decreased.

Inflammation-related protein expression in hepatic tissue. As is shown in Figs. 3 and 4, the levels of expression of various inflammation-related proteins, specifically, NF-кBp65, AP-1, iNOS, COX-2 and TGF- $\beta$ were significantly increased in the livers of diabetic control mice compared with those in non-diabetic mice. NF- $\mathrm{Bp} 65$ and AP-1 protein levels were reduced significantly to become comparable with those of normal mice following treatment with persicarin. In addition, TGF- $\beta$ and COX-2 protein expression levels were notably decreased by the administration of persicarin at a dose of $5 \mathrm{mg} / \mathrm{kg}$. Furthermore, iNOS protein expression was 
A

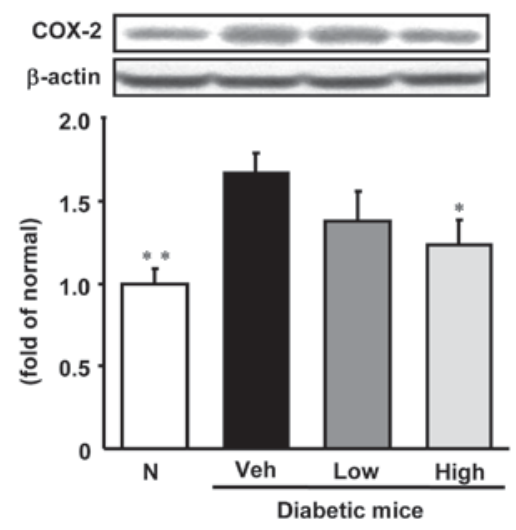

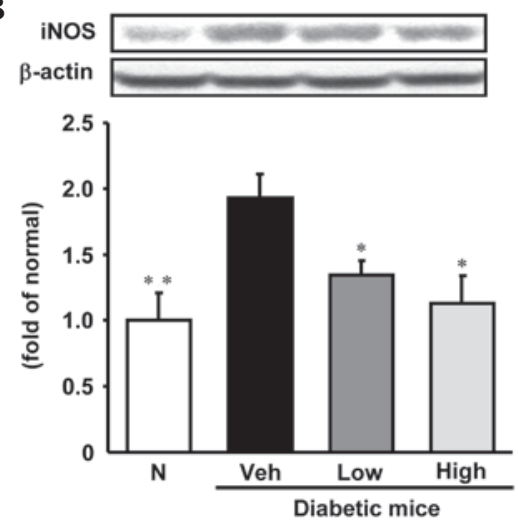

C

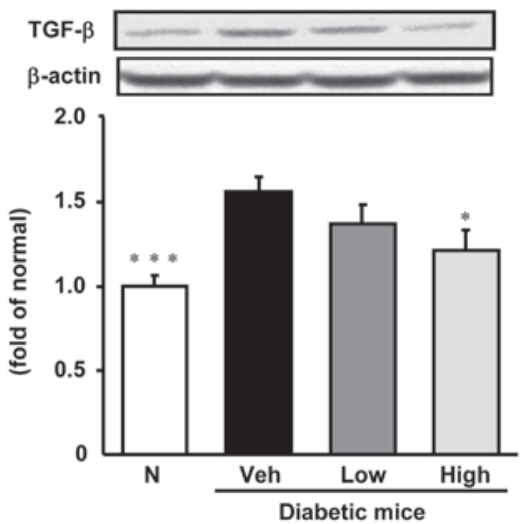

Figure 4. Expression of (A) COX-2, (B) iNOS and (C) TGF- $\beta$ protein in hepatic tissue. N, non-diabetic mice; veh, vehicle-treated diabetic mice; low, persicarin $2.5 \mathrm{mg} / \mathrm{kg}$ body weight-treated diabetic mice; high, persicarin $5 \mathrm{mg} / \mathrm{kg}$ body weight-treated diabetic mice; COX-2, cyclooxygenase-2; iNOS, inducible nitric oxide synthase; TGF- $\beta$, transforming growth factor- $\beta$. Data are the means \pm standard error of the mean $(\mathrm{n}=6)$. ${ }^{*} \mathrm{P}<0.05,{ }^{* *} \mathrm{P}<0.01,{ }^{* * *} \mathrm{P}<0.001$ vs. vehicle-treated diabetic mice.

significantly decreased in a dose-dependent manner by treatment with persicarin.

Hepatic histological examination. Histological evaluation of the hepatocellular damage was conducted (Fig. 5). The level of hepatocellular damage was higher in the vehicle-treated diabetic mice compared with normal mice. However, the administration of persicarin was observed to attenuate the hepatocellular damage in STZ-treated diabetic mice.

\section{Discussion}

O. javanica has been used for many years for the treatment of inflammatory conditions, including hepatic damage (24). Previous studies have shown that it possesses anti-hepatitis B virus (9), antithrombotic (10) and anticancer activities $(15,16)$. Moreover, persicarin, a major flavonoid component isolated from $O$. javanica has been reported to have a hypoglycemic effect in a type 1 diabetes model (12), and to inhibit oxidative stress and inflammation in human endothelial cells and sepsis-induced mice (17). In addition, persicarin has been reported to exhibit hepatoprotective effects through the inhibition of lipid peroxidation; however, its underlying beneficial effects on diabetes-induced liver damage are unclear (8). In the present study, the protective activities of persicarin against diabetes-induced liver damage were evaluated.

Diabetes is characterized by polyuria, polydipsia and polyphagia symptoms (25). STZ also leads to abnormal metabolism, including increases in food intake and water intake and decreases in body weight gain and liver weight $(26,27)$. In the present study, the administration of persicarin for 10 days led to no change in food or water intake, but body weight gain and liver weight were significantly increased by both doses (Table I). These results indicate that oral treatment with persicarin ameliorates some of the common symptoms of diabetes. Diabetic mice exhibited serum and hepatic glucose levels that were significantly increased compared with those in normal mice. The serum and hepatic glucose levels of the persicarin-treated diabetic mice were lower than those of the vehicle-treated diabetic mice (Table II).

The levels of glucose transporter 2 protein (GLUT2) are upregulated in a dose-dependent manner according to glucose concentration (28). In addition, liver GLUT2 protein levels are increased in diabetic rats and downregulated by insulin (29). On this basis, it is suggested that the reduction of the glucose content in the liver tissue involved an improvement of insulin resistance through GLUT2 activity.

Hyperglycemia is a primary cause of increased generation of ROS, leading to increased oxidative stress under conditions where the antioxidant defense is damaged. Hyperglycemia is a continuous cause of oxidative stress in diabetes (30-32). Oxidative stress plays a important role in the progression of liver damage (1). In addition, hepatic injury has been found to be associated with an increase in production of $\operatorname{ROS}(1,3)$. Mitochondria are one of the major sources of ROS, and they increase the production of ROS from the mitochondrial 

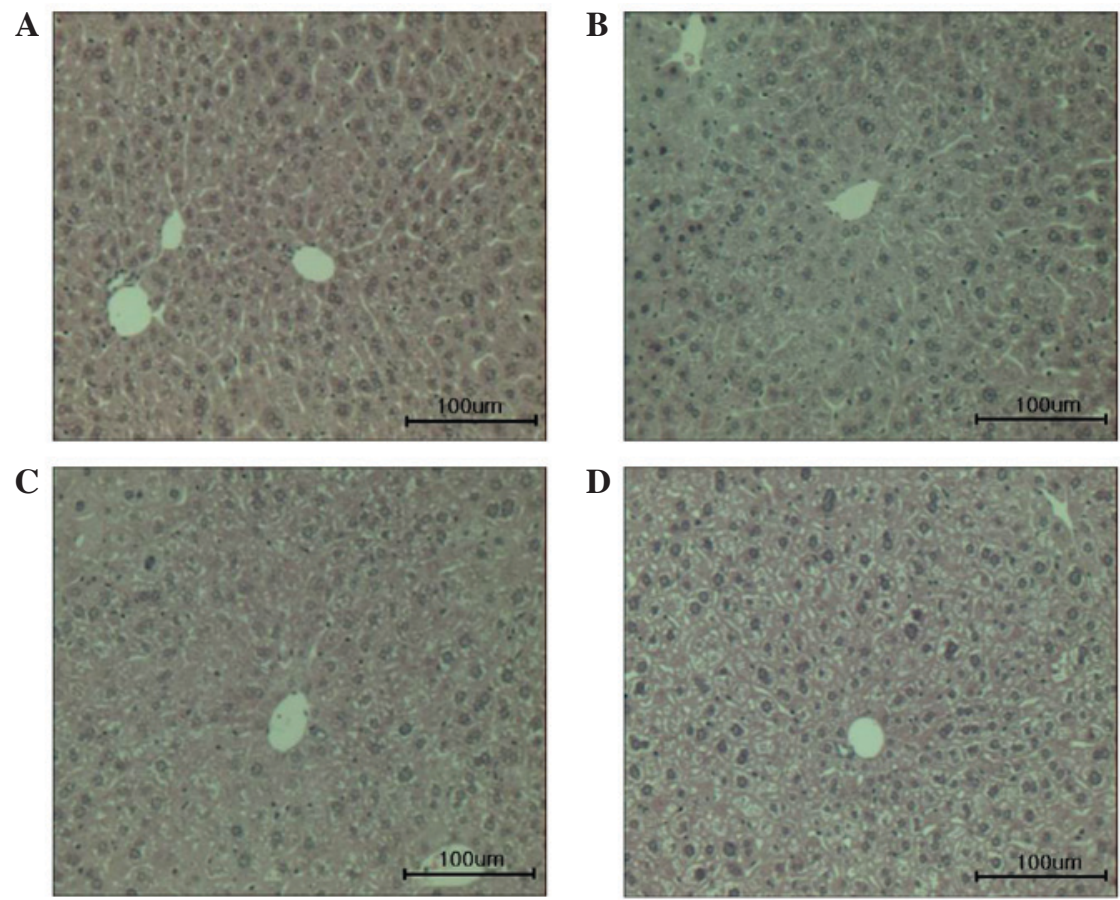

Figure 5. Hematoxylin and eosin staining of hepatic tissue in diabetic mice treated with persicarin for 10 days. (A) Non-diabetic mice, (B) vehicle-treated diabetic mice, (C) persicarin $2.5 \mathrm{mg} / \mathrm{kg}$ body weight-treated diabetic mice and (D) persicarin $5 \mathrm{mg} / \mathrm{kg}$ body weight-treated diabetic mice. Magnifcation, $\mathrm{x} 200$.

respiratory chain when they are functionally disordered (33). In hyperglycemia, NADPH oxidase is a main source of ROS production and the actions of mitochondrial respiratory chain complex enzymes are damaged as a result of continuous hyperglycemic conditions $(6,34)$. It is well recognized that in diabetic animal models, STZ results in the overexpression of ROS and generates nitric oxide (NO). NO combines with superoxide to form $\mathrm{ONOO}^{-}$, which causes lipid peroxidation, DNA damage and cell death. Therefore, it has a direct toxic effect on the liver leading to hepatic damage (35-37). In the present study, the elevated levels of NADPH oxidase subunits Nox-4 and p47 phox protein in the hepatic tissues of diabetic mice were notably reduced by the administration of persicarin. Moreover, the hepatic functional parameters ALT and AST of diabetic mice were markedly higher than those of normal mice; however, ALT and AST levels in the diabetic mice were significantly lowered by persicarin (Table II). These results suggest that persicarin improved hepatic functional parameters and exhibited hepatoprotective effects through downregulated oxidative stress via the modulation of Nox-4 and $\mathrm{p} 47^{\text {phox }}$ protein expression.

Oxidative stress mediated by hyperglycemia leads to the overexpression of the redox responsive transcription factor NF- $\kappa \mathrm{B}$ and AP-1, which modulates the increased gene expression required for the inflammatory response (38). Following an inflammatory response, the activation of NF- $\kappa \mathrm{B}$ induces downstream inflammatory mediators such as TGF- $\beta 1$, iNOS and COX-2 that have been reported to induce toxic effects in the liver (39). COX-2 is a key enzyme in prostaglandin biosynthesis from arachidonic acid and is associated with inflammatory processes (40). iNOS is another enzyme involved in inflammation and it catalyzes the formation of NO. NO reacts with superoxide to produce $\mathrm{ONOO}^{-}$, which is a highly ROS and leads to increased destructive and nitrosative

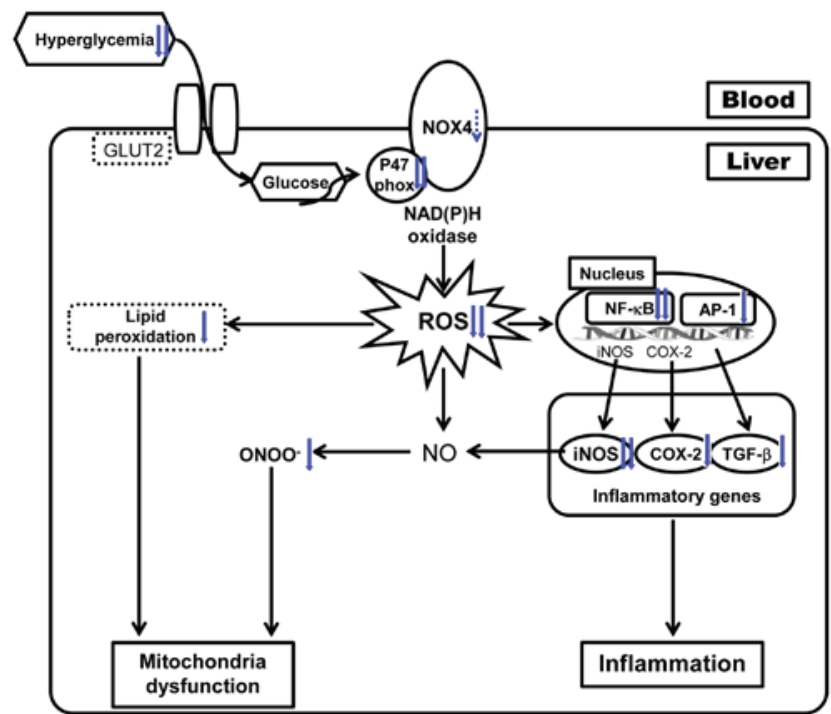

Figure 6. Predicted mechanism of persicarin against oxidative stress and inflammation in hepatic tissues. GLUT2, glucose transporter 2; ROS, reactive oxygen species; $\mathrm{NO}$, nitric oxide; $\mathrm{ONOO}^{-}$, peroxynitrite; iNOS, inducible NO synthase; COX-2, cyclooxygenase-2; TGF- $\beta$, transforming growth factor- $\beta$; $\mathrm{NF}-\kappa \mathrm{B}$, nuclear factor- $\mathrm{K}$; AP-1, activator protein-1.

stress (41). The overexpression of AP- 1 increases TGF- $\beta$ transcription, and AP- 1 elements are found in the TGF- $\beta$ promoter (42). In the present study, the livers of vehicle-treated diabetic mice showed significantly increased NF- $\mathrm{kB}$ and AP-1 levels in comparison with those of normal mice. However, the increased liver levels of NF-kB and AP-1 were notably reduced by persicarin. In addition, TGF- $\beta, \mathrm{COX}-2$ and iNOS expression levels in the livers of diabetic mice were markedly increased compared with those of normal mice. Administration of persicarin decreased the TGF- $\beta$ and COX- 2 expression 
levels; the reduction was significant at a dose of $5 \mathrm{mg} / \mathrm{kg}$. In addition, the iNOS expression level was significantly decreased by persicarin in a dose-dependent manner from a dose of $2.5 \mathrm{mg} / \mathrm{kg}$ through the $\mathrm{NF}-\kappa \mathrm{B}$ pathway. In the present study, the elevated protein expression of transcription factors $(\mathrm{NF}-\kappa \mathrm{B}$ and AP-1), pro-inflammatory enzymes (COX-2 and iNOS) and pro-inflammatory cytokine (TGF- $\beta 1$ ) in the livers of diabetic mice were downregulated significantly by the administration of persicarin, suggesting that persicarin attenuates the inflammatory response by inhibiting the NF- $\mathrm{B}$ and AP-1 pathway. Results also indicate that persicarin suppressed the symptoms of type 1 diabetes in STZ-induced mice. Persicarin ameliorated abnormal hepatic metabolism by decreasing hyperglycemia and oxidative stress (declining glucose and ROS production). Also, persicarin attenuated the inflammation associated with AP-1, NF- $\kappa$ B, COX-2, TGF- $\beta 1$, and iNOS in the liver.

In conclusion, the results from this study suggest that persicarin protects against type 1 diabetes by attenuating oxidative stress and the inflammatory response under hyperglycemic conditions, as shown in Fig. 6. Thus, it is suggested that persicarin may be a potential therapeutic agent for the treatment of diabetic complications including hepatic damage and diabetic symptoms.

\section{References}

1. Shaw JE, Sicree RA and Zimmet PZ: Global estimates of the prevalence of diabetes for 2010 and 2030. Diabetes Res Clin Pract 87: 4-14, 2010.

2. King H, Aubert RE and Herman WH: Global burden of diabetes, 1995-2025: Prevalence, numerical estimates and projections. Diabetes Care 21: 1414-1431, 1998.

3. Harrison SA: Liver disease in patients with diabetes mellitus. J Clin Gastroenterol 40: 68-76, 2006.

4. Aalthira R and Jain V: Advances in management of type 1 diabetes mellitus. World J Diabetes 5: 689-696, 2014.

5. Baig NA, Herrine SK and Rubin R: Liver disease and diabetes mellitus. Clin Lab Med 21: 193-207, 2001.

6. Babior BM, Lambeth JD and Nauseef W: The neutrophil NADPH oxidase. Arch Biochem Biophys 397: 342-344, 2002.

7. Manna SK, Mukhopadhyay A and Aggarwal BB: Resveratrol suppresses TNF-induced activation of nuclear transcription factors NF-kappa B, activator protein-1, and apoptosis: Potential role of reactive oxygen intermediates and lipid peroxidation. J Immunol 164: 6509-6519, 2002.

8. Park JC, Yu YB, Lee JH, Hattori M, Lee CK and Choi JW: Persicarin effect of Oenanthe javanica on the hepatic lipid peroxidation in bromobenzene-treated rats and its bioactive component. J Med Plant Res 62: 488-490, 1996.

9. Han YQ, Huang ZM, Yang XB, Liu HZ and Wu GX: In vivo and in vitro anti-hepatitis B virus activity of total phenolics from Oenanthe javanica. J Ethnopharmacol 118: 148-153, 2008.

10. Ku SK, Kim TH, Lee S, Kim SM and Bae JS: Antithrombotic and profibrinolytic activities of isorhamnetin-3-O-galactoside and hyperoside. Food Chem Toxicol 53: 197-204, 2013.

11. Ji G, Yao X, Zang Z and Huang Z: Antiarrhythmic effect of Oenanthe javanica (B1.) DC. Injection. Zhongguo Zhong Yao Za Zhi 15: 429-431, 448, 1990 (In Chinese).

12. Yang XB, Huang ZM, Cao WB, Zheng M, Chen HY and Zhang JZ: Antidiabetic effect of Oenanthe javanica flavones. Acta Pharmacol Sin 21: 239-242, 2000.

13. Kim JY, Kim KH, Lee YJ, Lee SH, Park JC and Nam DH: Oenanthe javanica extract accelerates ethanol metabolism in ethanol-treated animals. BMB Rep 42: 482-485, 2009.

14. Ma CJ, Lee KY, Jeong EJ, Kim SH, Park J, Choi YH, Kim YC and Sung SH: Persicarin from water dropwort (Oenanthe javanica) protects primary cultured rat cortical cells from glutamate-induced neurotoxicity. Phytother Res 24: 913-918, 2010
15. Kim JE, Lee DE, Lee KW, Son JE, Seo SK, Li J, Jung SK, Heo YS, Mottamal M, Bode AM, et al: Isorhamnetin suppresses skin cancer through direct inhibition of MEK1 and PI3-K. Cancer Prevention Research (Phila) 4: 582-591, 2011.

16. Ma G, Yang C, Qu Y, Wei H, Zhang T and Zhang N: The flavonoid component isorhamnetin in vitro inhibits proliferation and induces apoptosis in Eca-109 cells. Chem Biol Interact 167: $153-160,2007$.

17. Kim TH, Ku SK and Bae JS: Persicarin is anti-inflammatory mediator against HMGB1-induced inflammatory responses in HUVECs and in CLP-induced sepsis mice. J Cell Physiol 228: 696-703, 2013.

18. Park JC, Young HS, Yu YB and Lee JH: Isorhamnetin sulphate from the leaves and stems of Oenanthe javanica in Korea. Planta Med 61: 377-378, 1995.

19. Momose T, Yano Y and Ohashi K: Organic analysis. XLIV. A new deproteinizing agent for determination of blood sugar. Chem Pharm Bull (Tokyo) 11: 968-972, 1963.

20. Ali SF, LeBel CP and Bondy SC: Reactive oxygen species formation as a biomarker of methylmercury and trimethyltin neurotoxicity. Neurotoxicology 13: 637-648, 1992.

21. Mihara M and Uchiyama M: Determination of malonaldehyde precursor in tissues by thiobarbituric acid test. Anal Biochem 86: 271-278, 1978

22. Kooy NW, Royall JA, Ischiropoulos H and Beckman JS: Peroxynitrite-mediated oxidation of dihydrorhodamine 123. Free Radic Biol Med 16: 149-156, 1994

23. Komatsu S: Extraction of nuclear proteins. Methods Mol Biol 355: 73-77, 2007.

24. Park JC, Yu YB and Lee JH: Isolation of steroids and flavonoids from the herb of Oenanthe javanica DC. Korean J Pharmacogn 24: 244-246, 1993.

25. Okon UA, Owo DU, Udokang NE, et al: Oral administration of aqueous leaf extract of Ocimum gratissimum ameliorates polyphagia, polydipsia and weight loss in streptozotocin-induced diabetic rats. Am J Med Med Sci 2: 45-49, 2012.

26. Punithavathi VR, Anuthama R and Prince PS: Combined treatment with naringin and vitamin $\mathrm{C}$ ameliorates streptozotocin-induced diabetes in male Wistar rats. J Appl Toxicol 28: 806-813, 2008

27. Moraes IB, Manzan-Martins C, de Gouveia NM, Calábria LK, Hiraki KR, Moraes Ada S and Espindola FS: Polyploidy analysis and attenuation of oxidative stress in hepatic tissue of STZ-induced diabetic rats treated with an aqueous extract of Vochysia rufa. Evid Based Complement Alternat Med 2015: 316017, 2015.

28. Rencurel F, Waeber G, Antoine B, Rocchiccioli F, Maulard P, Girard J and Leturque A: Requirement of glucose metabolism for regulation of glucose transporter type 2 (GLUT2) gene expression in liver. Biochem J 314: 903-909, 1996.

29. Burcelin R, Eddouks M, Kande J, Assan R and Girard J: Evidence that GLUT-2 mRNA and protein concentrations are decreased by hyperinsulinaemia and increased by hyperglycaemia in liver of diabetic rats. Biochem J 288: 675-679, 1992.

30. Lee SH, Heo SJ, Hwang JY, Han JS and Jeon YJ: Protective effects of enzymatic digest from Ecklonia cava against high glucose-induced oxidative stress in human umbilical vein endothelial cells. J Sci Food Agric 90: 349-356, 2010

31. Aljofan M and Ding H: High glucose increases expression of cyclooxygenase- 2 , increases oxidative stress and decreases the generation of nitric oxide in mouse microvessel endothelial cells. J Cell Physiol 222: 669-675, 2010.

32. Sayed AA, Khalifa M and Abd el-Latif FF: Fenugreek attenuation of diabetic nephropathy in alloxan-diabetic rats: Attenuation of diabetic nephropathy in rats. J Physiol Biochem 68: 263-269, 2012.

33. Friederich M, Hansell P and Palm F: Diabetes, oxidative stress, nitric oxide and mitochondria function. Curr Diabetes Rev 5: 120-144, 2009.

34. Sedeek M, Callera G, Montezano A, Gutsol A, Heitz F, Szyndralewiez C, Page P, Kennedy CR, Burns KD, Touyz RM and Hébert RL: Critical role of Nox4-based NADPH oxidase in glucose-induced oxidative stress in the kidney: Implications in type 2 diabetic nephropathy. Am J Physiol Renal Physiol 299: F1348-F1358, 2010.

35. Cos P, Ying L, Calomme M, Hu JP, Cimanga K, Van Poel B, Pieters L, Vlietinck AJ and Vanden Berghe D: Structure-activity relationship and classification of flavonoids as inhibitors of xanthine oxidase and superoxide scavengers. J Nat Prod 61: 71-76, 1998. 
36. Obrosova IG: Diabetes and the peripheral nerve. Biochim Biophys Acta 1792: 931-940, 2009.

37. Drel VR, Lupachyk S, Shevalye H, Vareniuk I, Xu W, Zhang J, Delamere NA, Shahidullah M, Slusher B and Obrosova IG: New therapeutic and biomarker discovery for peripheral diabetic neuropathy: PARP inhibitor, nitrotyrosine and tumor necrosis factor-\{alpha\}. Endocrinology 151: 2547-2555, 2010.

38. Kuhad A and Chopra K: Attenuation of diabetic nephropathy by tocotrienol: Involvement of $\mathrm{NF \kappa B}$ signaling pathway. Life Sci 84: 296-301, 2009.

39. Garcia-Mediavilla V, Crespo I, Collado PS, Esteller A, Sánchez-Campos S, Tuñón MJ and González-Gallego J: The anti-inflammatory flavones quercetin and kaempferol cause inhibition of inducible nitric oxide synthase, cyclooxygenase- 2 and reactive C-protein, and down-regulation of the nuclear factor kappa B pathway in Chang Liver cells. Eur J Pharmacol 557: 221-229, 2007.
40. Dubois RN, Abramson SB, Crofford L, Gupta RA, Simon LS, Van De Putte LB and Lipsky PE: Cyclooxygenase in biology and disease. FASEB J 12: 1063-1073, 1998.

41. Llorens $\mathrm{S}$ and Nava E: Cardiovascular diseases and the nitric oxide pathway. Curr Vasc Pharmacol 1: 335-346, 2003.

42. Kim SJ, Glick A, Sporn MB and Roberts AB: Characterization of the promoter region of the human transforming growth factor-betal gene. J Biol Chem 264: 402-408, 1989. 